\title{
Online Music Piracy: Are Lawsuits The Best Approach?
}

Claire R. La Roche, (E-mail: larochecr@longwood.edu), Longwood University Mary A. Flanigan, Longwood University

Melanie B. Marks, Longwood University

\begin{abstract}
In the age of digital technology, perfect copies of sound recordings may be easily made and shared in violation of copyright law. Music piracy in the form of illegal downloading is a worldwide phenomenon that has a significant impact on the music industry. In response to the perceived threat to the music industry, lawsuits have been filed in the United States and abroad based on copyright infringement for illegally downloading music. This paper examines copyright law, case law, and recent litigation. In the wake of legal efforts to curtail illegal downloading, a survey of 112 undergraduate students was conducted in an effort to determine whether the lawsuits filed by the music industry are a deterrent to downloading music. Potential solutions are proposed and economic consequences discussed.
\end{abstract}

\section{Introduction}

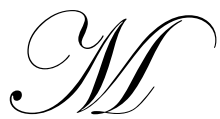

usic piracy in the form of illegal downloading of a copyrighted recording is a worldwide phenomenon that has prompted the music industry to file lawsuits for copyright infringement. Digital technology makes the music industry vulnerable to music piracy because perfect copies of sound recordings may be easily made and shared peer-to-peer (P2P). The Recording Industry Association of America (RIAA) represents $90 \%$ of recording artists worldwide. Although their claim is contested by others, and contradicted by their own figures, the RIAA estimates that illegal file sharing is responsible "for a 31 percent decline in compact disc music sales in the last three years" (Associated Press, 2003). In an effort to curtail illegal file swapping, the recording industry has responded by filing lawsuits and petitioning courts to issue cease and desist orders.

\section{Historical Response to Technological Change}

It is interesting to note that P2P file sharing is not the first technological change that challenged intellectual property rights associated with the music industry. At the turn of the nineteenth century, the Aeolian Music Company sought to boost sales of their player pianos by acquiring the copyrights to 381,589 musical compositions (Patry, vol. I, p. 798). The Aeolian Music Company wanted to prevent their competitors from being able to use these songs and thereby create a monopoly. Due to several unfavorable court decisions, the Aeolian Music Company was unsure of the scope of their rights associated with the copyrights they had acquired. Thus, Aeolian felt compelled to promote and finance the White-Smith Music Publishing Company v Apollo Company as a test case (Patry, p. 798).

In White-Smith Music Publishing Company v. Apollo Company (1909), the United States Supreme Court held that perforated rolls used in player pianos do not constitute copyright infringement. As a result of the WhiteSmith case, copyright law was amended in 1909 and the "compulsory license" was developed. The new law provided that "after the initial authorized recording of the work had been made, any other person was permitted to make "similar use" of the copyrighted work upon payment to the copyright proprietor a royalty of two cents "on each part manufactured"” (Patry, p. 59). While the new law added coverage of reproduction of works by 
mechanical means, Congress provided statutory protection for the new technology and White-Smith was not overturned. Player piano rolls remained exempt from copyright coverage (Patry, p. 59).

Radio broadcasting had not yet been developed when the amendments to the Copyright Act were passed in 1909. Thus, the advent of radio presented a new technological challenge to copyright protection. In the landmark case of Buck v. Jewell-LaSalle Realty Co. (1931), Gene Buck, the president of the American Society of Composers, Authors, and Publishers (ASCAP) filed suit against Jewell-LaSalle Realty Company, the owner of the LaSalle Hotel, and Wilson Duncan, the owner and operator of a radio station in Kansas City, Missouri for allegedly violating copyrights held by members of ASCAP. The alleged copyright infringement was in the form of broadcasting radio over loud speakers in the LaSalle Hotel. On appeal, the United States Supreme Court held that when a hotel provides a radio broadcast to patrons via a master radio receiving set and loud speakers, the hotel is engaging in a public performance that is protected by copyright law.

The music industry realized that radio actually promoted music sales. Ultimately, the copyright infringement issues associated with radio were resolved by the formation of performing rights organizations (PRO). Today, songwriters and music publishers voluntarily join a PRO. For a fee, a PRO issues a voluntary blanket license to radio stations and other broadcasting entities. In the U.S., ASCAP, SESAC, and Broadcast Music Inc. (BMI) are the primary PROs. They monitor the frequency songs are played and distribute to their members fees collected. (Avalon, 2002, p. 35) This system of voluntary licensing worked with radio because virtually all copyright holders agreed to forego lawsuits and to license others to broadcast their work.

\section{Copyright Law as a Deterrent to Online Piracy}

The purpose of copyright protection is to encourage the creation of artistic and literary works by providing economic incentives to be creative. In essence, copyright law creates a temporary monopoly by granting the holder of a copyright the exclusive right to 1) use, 2) reproduce, 3) publicly perform, and/or 4) display a musical, literary, or artistic work during the effective term of the copyright.

Copyright law is national legislation and each country establishes its own civil remedies and criminal sanctions for copyright violations. The Berne Convention for the Protection of Literary and Artistic Works is an international copyright treaty ratified by 96 countries. Initially, the Berne Convention was entered into in 1886 and the U.S. became a signatory country in 1989. The goals of the Berne Convention include the development of standards of copyright protection and the mutual recognition of copyrights among the signatory countries.

Even with the threat of significant criminal and civil penalties, it is estimated that 57 million Americans are engaging in P2P file-swapping (McGuire, March 31, 2004). In the U.S., civil penalties may be recovered for actual damages incurred by the holder of the copyright plus the profits earned by the infringer (17 U.S.C. §504(a) (1)). As an alternative civil remedy, the copyright holder may elect to recover statutory damages from the infringer up to $\$ 30,000$ per work or in the case of willful or intentional infringement, up to $\$ 150,000$ per incident (17 U.S.C. $\$ 504(c)(1)(2))$. Certain copyright infringements of sound recordings including reproduction or distribution by digital means may be criminally prosecuted. The No Electronic Theft Act (NET) makes willful copyright infringement for commercial advantage or private gain a crime. To penalize individuals who participate in largescale, peer-to-peer, file sharing, reproduction or distribution by electronic means of copyrighted work whose total retail value exceeds $\$ 1,000$ during any 180 -day period may be fined and imprisoned for up to one year. Courts may punish any person found guilty of criminal copyright infringement of copyrighted works having a total value of $\$ 2,500$ by up to 3 years in prison. For subsequent criminal copyright convictions, prison terms of up to six years in length may be imposed (17 U.S.C. \$506, 18 U.S.C. \$2319(c) 3). Although the Justice Department has the authority to prosecute P2P file-swapping under NET, thus far they have declined to do so (McCullagh, 2004).

On March 31, 2004, a House Judiciary subcommittee passed the Piracy Deterrence and Education Act of 2004 (PDEA). "The bill targets people who trade more than 1,000 songs on peer-to-peer (P2P) networks like KaZaa and Morpheus, as well as people who make and sell bootlegged copies of films still in cinematic release." (McGuire) If signed into law, this version of the PDEA would punish P2P file-swappers with up to three years in 
prison and repeat offenders could serve up to six years. In addition, an Internet Use Education Program would be established (PDEA).

\section{Impact of P2P File-Sharing on CD Sales}

While it is difficult to accurately assess the monetary effects of illegal downloading, an estimated 2.3 billion songs are illegally downloaded each month (PDEA). It is important to note that not all songs downloaded would have been purchased on CD. In other words, there is a tendency to download songs that a file swapper would never have purchased in a retail store. In the authors' survey of 112 students (hereinafter referred to as the Student Survey), when asked to assess the statement that they "generally download music CDs that they would not consider buying in a store", only $20.5 \%$ disagreed with this statement.

As indicated by Table 1 below, the RIAA maintains that there has been a significant decline in the number of CDs shipped per year since 2000. From 2000 to 2003, the RIAA Yearend Statistics indicate that there was a $20.9 \%$ decline in the number of CDs shipped per year. During the same period the average unit price increased by $7.4 \%$, resulting in a decline in the retail value of units shipped over the same time period of only $15 \%$. It is important to note that RIAA Yearend statistics are based on units shipped and not units sold. Unsold units may be returned to the record companies. Therefore, it is easy to envision a scenario where numbers reported in any given period do not accurately reflect sales. For example, in a recent article written by Moses Avalon, he reports that RIAA's claim of lost sales is at odds with point of sales figures reported by Soundscan, a service of Nielsen, showing approximately a 10\% increase in CD sales from the first quarter of 2004 as compared to the first quarter of 2003. The following is a simple example Avalon used to illustrate his point. "I shipped 1000 units last year and sold 700 of them. This year I sold 770 units but shipped only 930 units. I shipped 10\% (sic) less units this year. And this is what the RIAA wants the public to accept as a "loss"” (Avalon, 2004).

Table 1

\begin{tabular}{|c|c|c|c|c|c|}
\hline $\begin{array}{l}\text { Dollar Value of Units Shipped Based } \\
\text { on Suggested Retail Price* }\end{array}$ & 2000 & 2001 & 2002 & 2003 & $\begin{array}{l}\text { Percentage Change } \\
\text { from 2000 }\end{array}$ \\
\hline \$ Value of CD Units Shipped & $13.2 \mathrm{~B}$ & $12.9 \mathrm{~B}$ & $12.04 \mathrm{~B}$ & $11.23 \mathrm{~B}$ & $-15.0 \%$ \\
\hline CD Units Shipped & $.94 \mathrm{~B}$ & $.88 \mathrm{~B}$ & $.80 \mathrm{~B}$ & $.75 \mathrm{~B}$ & $-20.9 \%$ \\
\hline Average Unit Price & 14.02 & 104.64 & 14.99 & 15.06 & $+7.4 \%$ \\
\hline
\end{tabular}

*Digital Download sales not included

The music industry alleges that illegal file sharing has also had a deleterious effect on international sales. For instance, the results of a study by Music Industry Piracy Investigations (MIPI) indicate that approximately 7 million Australians illegally downloaded over 100 million songs in the past year (Ceola, 2003). EMI Australia contends that, online music piracy has had a negative impact on the Australian music industry and estimates "more than $\$ 150$ million in lost revenue to the artists, songwriters, music companies and retailers" (Ceola, 2003). In another recent study commissioned by the British Phonographic Institute (BPI), "some 8 million people now download music from the Internet and 7.4 million - or 92\% - admit doing so illegally" (AP Online, 2004). BPI estimates that as a result of online piracy, "consumers are expected to spend $32 \%$ less on albums and $59 \%$ less on singles than they did last year..." (AP Online, 2004). Arguably, the significant decline in revenue from the sale of CD singles is unrelated to P2P file sharing. CD singles are inconvenient and relatively expensive and thus have not been favored by consumers. In fact, the RIAA is no longer even tracking the sale of CD singles in their Yearend Statistics (RIAA).

The Pew Charitable Trusts have funded The Pew Internet and American Life Project, an initiative exploring the impact of the Internet. A Pew Internet Project Data Memo indicates that "musicians are quite divided in their opinions about the impact of file sharing" on the music business (Rainie and Madden, 2004). As a part of the Pew Internet and American Life Project, 2,755 musicians were surveyed online. When asked whether the RIAA's legal actions against individuals illegally downloading music will "ultimately benefit musicians and 
songwriters", $60 \%$ said that the RIAA's actions were of no benefit and $18 \%$ did not know. When asked whether "file sharing on the Internet poses a MAJOR threat to creative industries like music and movies, a MINOR threat, or that it poses no real threat at all", only $30 \%$ responded that it poses a major threat, $32 \%$ said that it poses a minor threat, 31\% said that it poses no real threat at all, while 7\% did not know (Rainie and Madden, 2004).

There are several other factors that must be considered in evaluating the decline in CD sales. In the 1990's, consumers were purchasing music in CD format for the first time. During that period, the technology to transfer one's personal music files from tape format to $\mathrm{CD}$ format was very limited and expensive. Consequently, many consumers were purchasing CDs to replace music that had been previously acquired. Buying old music in the new CD format may account for some of the CD sales growth in the 1990's (Raba, 2003).

It has also been argued that consolidations of radio stations and in the recording industry have at least in part been responsible for this decline in music sales (Bernstein, 2004). When Congress passed the Telecommunications Act of 1996, over six decades of regulations limiting the number of radio stations that a person or entity could own were eliminated. As a direct result of removing these restrictions, "The music and news delivered to over half (of) the music audience is controlled by 4 giant corporations" (Moyers, 2002). In the wake of deregulation, the role of DJs (now referred to as "air personalities") has also changed. No longer are DJs given the freedom to select the music for their programs. Consultants, computers, and committees select the music that is aired (Moyers, 2002). The bottom line is that deregulation in radio has meant that the music being played is more homogeneous and that listeners have fewer choices. It is arguable that restricting the variety of music available to radio listeners could also account for the sale of fewer CDs.

Finally, the decline in CD sales could be a result of the general state of the economy. From 2000 to 2002, the U.S. was experiencing an economic downturn. To exacerbate the situation, according to RIAA Yearend Statistics, the average retail unit price of a CD increased from $\$ 14.02$ in 2000 to $\$ 14.99$ in 2002 (RIAA).

\section{Legal Responses to Online Music Piracy}

In an attempt to curtail illegal peer-to-peer swapping of music files, the music industry has filed lawsuits seeking to protect their copyrights. Between September 8, 2003 and March 24, 2004, the RIAA filed suit against 1,977 defendants for copyright infringement (Viega, 2004). The RIAA has settled 400 of these lawsuits out-of-court at an average cost of $\$ 3,000$ (Zeidler, 2004).

The music industry in Australia recently prosecuted undergraduate students for criminal copyright infringement related to online music piracy. Although the judge in these cases suspended the 18-month prison sentence, he noted, "Student music pirates deserve to be imprisoned" and discounted the argument that "everyone is doing it" (Needham and Jinman, 2003, p. 29). The average age of the defendants combined with the fact that the students had no money persuaded the judge to suspend the sentences. In addition to individuals being prosecuted, the Australian Recording Industry Association (ARIA) has filed suit against E-Talk Communications, an Internet Service Provider (ISP). As a result of lost revenue, the music industry in Australia is "extending their actions to individuals and universities" (Ceola, 2003).

On March 30, 2004, the International Federation of the Phonograph Industry (IFPI) announced that lawsuits are also being filed by recording industry groups in Germany, Denmark, Italy, and Canada (AP Worldstream, 2004). On April 22, 2004, the United States Department of Justice announced that they had begun 'Operation Fastlink', "the largest multi-national law enforcement effort ever directed at online piracy" (DOJ Press Release, 2004). The U.S. along with 10 other countries conducted over 120 searches worldwide in a concerted effort directed at eliminating online piracy. According to Attorney General John Ashcroft, "The amount of international coordination and cooperation in this effort is unprecedented and will send a clear and unmistakable message to those individuals and organizations dedicated to piracy that they will no longer be protected by geographic boundaries" (DOJ Press Release, 2004). 


\section{Are Lawsuits an Effective Deterrent?}

Six months after the RIAA began filing lawsuits against people for illegally sharing music files, 112 undergraduate students at a small state university were surveyed about downloading music over the Internet. Of the respondents, $84.8 \%$ own a CD burner and $84.8 \%$ admitted to downloading music over the Internet. Only 1 person $(.9 \%)$ had ever paid for downloading music. In response to whether they thought that downloading without paying is illegal, $64.3 \%$ acknowledged that it is against the law while only $22.4 \%$ believe that downloading music for free is unethical.

According to the students surveyed, the RIAA lawsuits have had some impact on their peer-to-peer downloading. Of the students surveyed, $83.7 \%$ were aware that the music industry has filed lawsuits against 1,977 people for illegally downloading music and $9.8 \%$ knew someone who had been sued or received a cease and desist order. After students became aware of the lawsuits, $43 \%$ were more hesitant about downloading. Since becoming aware of these lawsuits, $35 \%$ of the students who had previously downloaded music had refrained from illegal file sharing. Of the students who knew someone who had been sued for copyright infringement or received a cease and desist order, only $44 \%$ admitted to continuing to illegally downloading music (approximately a $40 \%$ decrease). Moreover, once students knew someone who had been sued, $92 \%$ changed their downloading habits by ceasing, becoming more selective, or more hesitant to swap files peer-to-peer.

While the Student Survey sample size was somewhat small, the results of this survey are corroborated by the Pew Internet Project poll, a national survey of 1,371 adult Internet users based on phone interviews conducted between February 3, 2004 and March 1, 2004. According to the Pew poll, 33\% of those Internet users who had downloaded music in the past stopped downloading music files and 38\% download music files less often as a result of the RIAA lawsuits (Rainie and Madden).

\section{Economic Framework for Analysis}

The music industry argues that online piracy has caused significant declines in CD sales. The first relevant economic question is whether the ability to download music commercially available as CDs is an economic substitute or a complement for purchasing CDs. For example, if a person downloads a song, does this mean that the $\mathrm{CD}$ will not be purchased or is it possible that individuals explore online music sources and then purchase compact discs of artists they enjoy? Research by Oberholzer and Strumpf (2004) suggests that this complementary impact exists for "superstar" albums - downloading results in increased sales of compact discs. The impact appears to be the opposite for albums that are less popular, with sales of compact discs decreasing as a result of downloading. The authors claim that this impact, however, is statistically indistinguishable from zero. They conclude, based upon their most pessimistic model aimed at showing the worst-case scenario for the industry, that downloading of music would have resulted in a loss of 2 million albums, just a small fraction of the decline in the industry. Thus, according to the authors, downloading, does not explain the large decrease in sales reported for the industry between 2000 and 2002. Instead, they summarize other events that could negatively impact album sales including a declining economy, a reduction in albums released by the industry, emerging forms of competition in the entertainment field (DVDs, video games), and possible consumer backlash (they refer to a movement to boycott major labels). The authors also reiterate a claim made by others that sales of discs may have been unusually high in the 1990s as people replaced tapes and records with the new technology. The general conclusion of the study, that "file sharing has no statistically significant effect on purchases of the average album" disputes those of RIAA and researchers at other institutions.

Hui and Png (2003) support the idea that piracy and compact disc sales act as substitutes. The authors claim that piracy has resulted in loss of sales of approximately $6.6 \%$. While this is significant, it is less than half of the estimate made by the music industry. Zetner (2004) offers a slightly higher estimate with a decline in the range of $7.8 \%$ to $14.5 \%$ for music sales.

As indicated by Table 2 below, the Student Survey seems to indicate that for undergraduate students, downloaded music is more often than not a substitute good. This assertion is based on the assumption that those 
surveyed are each downloading approximately the same amount of music. The fact that college students have very little surplus money could be part of the reason that downloading is not more complementary.

Table 2

\begin{tabular}{l|ccccc}
\hline Statement & $\mathbf{0 \%}$ of the time & $\mathbf{2 5 \%}$ of the time & $\mathbf{5 0 \%}$ of the time & $\mathbf{7 5 \%}$ of the time & Always \\
\hline $\begin{array}{l}\text { When I download a song: I } \\
\text { will not buy the CD. }\end{array}$ & $5.2 \%$ & $18.6 \%$ & $29.9 \%$ & $26.8 \%$ & $19.6 \%$ \\
$\begin{array}{l}\text { When I download a song: I } \\
\text { then do buy the CD. }\end{array}$ & 29.9 & 35.1 & 26.8 & 7.2 & 1.0 \\
\hline
\end{tabular}

For $19.6 \%$ of the Student Survey respondents, downloading acts as a perfect substitute for purchasing while $75.3 \%$ report that there is some degree of substitutability. Only 5.2\% of the survey respondents deny any substitutability. Similar results are found when exploring complementarity. Of the survey respondents, only $1 \%$ maintains that downloading and purchasing are perfect complements, $69.1 \%$ respond that there is some lesser degree of complementarity, and $29.9 \%$ claim that there is no complementary relationship at all.

Results of the survey administered by Oberholzer and Strumpf (2004) of 159 individuals who were engaged in downloading activities suggest that there is a net positive effect on compact disc sales, that using downloading as a way to learn about artists dominated the effect of downloading discouraging purchase of a compact disc. The outcome of the Student Survey response to the statement "Having the ability to download music results in my buying more CDs" and "Having the ability to download music results in my buying fewer CDs." are shown on Table 3 below. The Student Survey suggests that the relationship appears to be one of substitutes more so than complements. Unfortunately, the survey did not ask students to quantify their behavior thus limiting the conclusions generated. Again, this effect could be due in part to lack of disposable income. However, 59.6\% said that it was true or somewhat true that they downloaded music they would not have purchased anyway.

Table 3

\begin{tabular}{lccccc}
\hline Buy More CDs & Frequency & Percent & Buy Fewer CDs & Frequency & Percent \\
\hline Definitely true & 11 & 11.1 & Definitely true & 33 & 33.3 \\
Somewhat true & 19 & 19.2 & Somewhat true & 28 & 28.3 \\
Neither true nor untrue & 20 & 20.2 & Neither true nor untrue & 15 & 15.2 \\
Somewhat untrue & 15 & 15.2 & Somewhat untrue & 12 & 12.1 \\
Definitely untrue & 34 & 34.3 & Definitely untrue & 11 & 11.1 \\
\hline
\end{tabular}

If downloaded music and commercially available compact discs are indeed complements, then it would be economically rational for the music industry to find some mechanisms for organizing and charging for this service. This would be true even if the effect only held true for superstar albums, given that they drive most of the revenues for record labels. There could be some markets that would generate less revenue, perhaps where the target audience is small. But overall, the industry would be likely to capture greater revenues.

\section{Rationality of Lawsuits}

If Oberholzer and Strumpf are correct and there is a complementary relationship between downloading and $\mathrm{CD}$ sales, then it is easy to conclude that litigation efforts on the part of the music industry would not be a rational activity. If RIAA, Zetner, Hui and Png, and the Student Survey indicating that downloading of music and retail sales of compact discs are substitutes is correct, then the rash of litigation directed at both firms and individuals might indeed be a rational response. For litigation to be economically rational, one of three scenarios would have to prevail: 
a. Damages collected exceed the cost of litigation. In this case, there would be no reason for the music industry not to undertake litigation since it would be revenue enhancing. This would be true if the costs of litigation were small or the damages collected were large. However, it is not obvious that this scenario is realistic. First, the music industry has been relatively unsuccessful in suing companies that facilitate downloading of music. Consequently, the RIAA is suing individuals on a case-by-case basis and this is an expensive and time-consuming process made more difficult by the recent RIAA v. Verizon (2003) case. In RIAA v. Verizon (2003), the RIAA sought to use the subpoena provision of the Digital Millennium Copyright Act (DMCA) to force Verizon (the ISP) to reveal the identity of a subscriber allegedly using P2P software to illegally share music online. Verizon refused to reveal the identity of the subscriber because the copyrighted material did not reside on Verizon's computer. On appeal, the D.C. Circuit Court agreed with Verizon's interpretation of the DMCA subpoena power. This was a huge victory for Internet privacy advocates and online file-sharers. In order for RIAA and others to discover the identity of file sharers, they must file two lawsuits. To discover the identities of alleged online copyright infringers, they must first file a "John Doe" lawsuit. After the defendant's name is revealed, then a second lawsuit for copyright infringement is filed. It appears that many of these cases are being settled out of court for relatively small amounts of money. The costs associated with discovery, court costs, and attorneys' fees must still be paid. If litigation firms are charging contingent fees based on the damages recovered and not charging their customary hourly rates, then this entire scenario becomes more likely. However, a second scenario seems more likely.

b. $\quad$ Combination of damages collected and increased disc sales in period t exceed the cost of litigation in period $t$. In this case, litigation is used as a way of decreasing piracy and increasing compact disc sales. While damages alone might not cover the cost of litigation for some given period $t$, damages combined with the increased disc sales would cover the cost of litigation in period t. This scenario applies if period $t$ is relatively short. Neilsen owns a music rating service known as Soundscan "that tracks sales of music and music videos throughout the United States and Canada" (Neilsen). Soundscan uses barcodes to track point of sale purchases. Recently, Soundscan reported an almost $10 \%$ increase in CD sales from the first quarter of $2003(147,000,000)$ to the first quarter of $2004(160,000,000)$ (Avalon, 2004). If sales are going up as a result of lawsuits, then this case is more valid. However, if the tradeoff being made between up front litigation costs and greater disc sales extends into the future, then a third scenario is plausible.

c. The combination of damages collected plus present value of increased disc sales over time exceeds the cost of litigation in period $t$. In this case, the music industry might be taking an aggressive stance in period $t$ by launching a rash of lawsuits as a way of decreasing piracy now and in the future. The present value of the increased future income stream associated with higher disc sales must be discounted and weighed against the cost of litigation now. Combining damages collected and the present value of future disc sales that would have been lost to piracy might provide a compelling case for making an investment in litigation now, even if it does not pay for itself in a given period as implied by (b) and (c).

\section{Voluntary and Compulsory Licensing}

Even if downloaded music and commercially available compact discs are substitutes, there can still be a case for voluntary licensing. Wayne Rosso, President of Optisoft, a file-sharing company, supports this claim. He states that his company has been "trying for years to talk sense to these people and make them see" (McGuire, March 29, 2004) that the music industry is a market that easily lends itself to this kind of commercialization. Two cases are possible for supporting a move to voluntary licensing.

d. There is no case for suing supported by $(a),(b)$, or (c) above. In this situation, litigation would not be a rational strategy to pursue. In this case, then there is nothing to be lost by having a voluntary arrangement. If illegal downloading cannot be controlled through the threat of lawsuits, then the industry should organize itself and offer a comprehensive, fee-based downloading service. Any decrease in piracy and increased in fee-based downloading would be revenue enhancing for the industry. A second case might be plausible, even if there is a case for litigation as detailed above.

e. $\quad$ Revenue generated from licenses in period t exceeds the revenue lost from foregone disc sales in period $t$. Regardless of whether litigation pays for itself; voluntary licensing is rational if it increases revenue. This 
requires that the money collected from licenses in a fee-based downloading environment outweigh the revenue that would be lost from disc sales, as people substitute to the legal downloading option. Several factors could weigh in to this equation. First, there could be consumers who are pirating music now who would legally download music if the option were offered at a desirable price. The Student Survey indicates that only $.9 \%$ of respondents have ever paid to download music. These results suggest that the price would have to be lower than is currently offered by online providers such as Apple iTunes with a price of $\$ .99$ and Walmart.com with a price of $\$ .88$. Some anecdotal evidence suggests that lack of variety for existing firms offering this downloading service contributes to their lack of success. "Each month on average, 2,300,000,000 digital media files are transferred among users of peer-to-peer systems" (PDEA, Sec. 2 (3)). According to the free response question in the Student Survey, students are willing to pay an average of $\$ 3.79$ to download a personalized CD mix of 12 songs (\$.316 per song). Even with increased penalties for copyright infringement and convenient reasonably priced access to legal downloads, there will still be some free riders. Assuming that 2 billion of the 2.3 billion songs are legally downloaded at $\$ .25$ each, the music industry would benefit from a monthly revenue stream of $\$ 500,000,000$. Next, it is possible that individuals who neither pirate music online nor purchase discs would consume music from a fee-based downloading service. Such an individual might be one who does not wish to participate in illegal activities and does not wish to pay the high prices for compact discs that may have only a handful of songs he or she cares to own. If this market were captured, then the increase in consumption through a fee-based downloading operation would be completely revenue enhancing, as there is no offsetting substitution away from purchases of commercially available discs. Targeting this market would perhaps be the best way to make voluntary licensing arrangements viable. It is possible that period t could be multi-year, meaning that voluntary licensing might not be profitable in initial years, but they could be as CD burners become more commonplace in households.

In exploring the idea of voluntary licensing for fee-based downloading, the success of the idea hinges on acceptable pricing of the service, which could be a monthly fee or a per unit fee. Offered as a monthly fee, suppliers of this service have little or no control over the volume of downloading that will take place and therefore almost no control over the magnitude of any substitution effect away from compact discs. One can envision scenarios where individuals subscribe for one month and then download hundreds of songs. Unless contractual obligations on the part of consumers require multiple month contracts or limit the maximum number of downloads, such an arrangement might not be in the best interest of the supplier. Instead, it might make more sense to have a per-unit charge.

Some evidence suggests that per-song downloading prices could be lower than what is currently charged if services were offered directly from the firms holding the copyrights. In "Confessions of a Record Producer", Moses Avalon revealed that the proceeds of a $\$ 17 \mathrm{CD}$ with retail distribution would be divided as indicated in Table 5 below.

Table 5

\begin{tabular}{l|ccc}
\hline \multicolumn{1}{c|}{ Recipient } & $\begin{array}{c}\text { Amount Paid With Retail } \\
\text { Distribution }\end{array}$ & $\begin{array}{c}\text { Percentage Received With } \\
\text { Retail Distribution }\end{array}$ & $\begin{array}{c}\text { Amount Received With } \\
\text { Online Sale }\end{array}$ \\
\hline Retailer & 5.00 & $29.4 \%$ & .67 \\
Record Label & .67 & 3.9 & .67 \\
Container Charge & 4.25 & 25 & \\
Distributor & 2.40 & 14.1 & .0 .6 \\
Giveaways & 1.80 & 6.5 & .83 \\
Duplication/Recording & 1.10 & 4.9 & .60 \\
Artist Royalty & .83 & 3.5 & .27 \\
Songwriter's License & .60 & 1.6 & .085 \\
Producer Royalty & .27 & .5 & $\mathbf{\$ 2 . 4 5}$ \\
Musicians' Union & .085 & $\mathbf{1 0 0 \%}$ & \\
TOTAL & $\mathbf{\$ 1 7 . 0 0}$ & & \\
\hline
\end{tabular}


Under voluntary licensing, the cost structure to the music industry changes. Certain costs go away if music is provided in an on-line fee based environment. First, the share being paid to the retailer goes away, although it could be replaced with a much smaller per unit payment being made to an industry-wide middleman that manages the downloading environment. When music is downloaded the marginal cost of distribution and "giveaways" are not relevant. "Giveaways" are more than promotional CDs sent to radio stations. They are free goods given away "to induce a record store to pick up a new artist-like, buy two boxes and get one free" (Avalon, 2002, p. 58). Record companies charge a packaging fee also known as a container charge. As a general rule, the container charge is " $25 \%$ of the retail sales price of the $\mathrm{CD}$, or about $\$ 4.25$ " (Avalon, 2002, p. 57). An online distribution chain would make the container charge inapplicable since the cost of the container along with the costs of duplication are passed on to the consumer. The same album delivered in an online format, where these costs are not relevant, theoretically could cover costs at $\$ 2.45$.

Data collected at a local retailer showed that the average number of songs per new release to be 14.2 and for best sellers to be 14.4. Using an average of 14.3 songs per album, the average cost per song is $53.8 \notin$ by the time royalties go to the songwriter, producer, artist, musicians' union, and record label. With an online distribution channel, prices could be set that allowed royalties to be paid and included a profit for the record label. Currently some online services are offering downloads at \$.88 - \$.99 per song. However, indications are that they have not met with much success. If the music industry could establish a price that accurately reflects the cost savings as a result of online distribution, indications are that the market would accept the price. In the Student Survey, the 95\% confidence interval for the mean students are willing to pay to download a CD mix of 12 songs was between $\$ 3.52$ and $\$ 4.73$. According to the Student Survey, $91.8 \%$ of those surveyed think that CDs are too expensive. It could theoretically be possible that by lowering the price to download music, the music industry would not cannibalize retail sales to students and could capture the rents that are being lost due to illegal peer-to-peer file sharing. If consumers are price elastic demanders of music, then this is feasible and if they are price inelastic, then it is not.

A system of compulsory licensing similar to the mechanical license developed by the Copyright Act of 1909 is another option that could be imposed on the music industry. The rationale for the creation of the compulsory license in 1909 may have been spurred on by the fact that Aeolian Piano Company attempted to create a monopoly in what was a relatively new form of technology. The fact that player piano rolls were exempted from paying the royalties further supports this theory.

It is possible that compulsory licensing could be imposed on music downloads in an effort to force the music industry to recognize that the nature of the music business needs to keep up with the changing times and technological capabilities. With a compulsory license, firms holding copyrights would be required to make their music available to others in exchange for a statutory fee for each download. This arrangement already exists in the case of artists who want to record songs owned by others. The firm wishing to use the copyrighted material has the legal right to do so but must hold a compulsory license and pay the relevant fee per incidence. The major impediments to a compulsory licensing system include the difficulty of monitoring compliance with statutory requirements and collection of fees.

\section{Conclusion}

There are several factors other than online music piracy that could contribute to the decline in the sales of CDs from 2000 to 2003. In addition, the RIAA's practice of tracking shipments and not actual sales also makes it is difficult to determine whether sales of CDs have actually declined and to what extent. This is particularly true as music retailers move towards a just-in-time approach to managing their inventory (Avalon, 2004).

For some peer-to-peer file sharers, downloaded music is a complement while for others it is a substitute. Worldwide, peer-to-peer software programs have been downloaded 600,000,000 times (PDEA). "At any one time there are over 3,000,000 users simultaneously using just one of these services" (PDEA, Sec. 2 (3)). The number of individual file sharers in the U.S. alone is estimated to be 60 million (Evangelista, 2003). At the present rate of approximately 4,000 lawsuits a year, it would take the RIAA 15,000 years to legally pursue those people presently 
engaging in P2P file sharing. Thus, for the music industry to rely solely on lawsuits to protect intellectual property rights would be unwise.

Internet customers want easy, convenient, one-stop shopping. Advantages of online downloading for the music industry include: 1) lower costs of distribution, 2) shifting some of the production costs to the consumer, 3) a significant reduction in the demand for counterfeit CDs, 4) widespread distribution affording new artists access to a larger audience, and 5) arguably, increased retail sales of CDs.

Downloading music is here to stay. While lawsuits have been somewhat effective in discouraging illegal downloading, they are not enough to eliminate peer-to-peer file sharing. It would be prudent for the music industry to change its pricing and promote a uniform voluntarily licensing system for digital downloads. The time has come for the music industry to adopt a new business model that will serve as a viable alternative to illegal peer-to-peer file sharing before it goes the way of the player piano.

\section{References}

1. Associated Press (2003, September 8). "RIAA Lawsuit Orgy Underway". Wired News, www.wired.com/news/digiwood/0,1412,60341,00.html (accessed 9/19/2003).

2. Associated Press Worldstream (2004, March 30). "Recording industry group announces wave of legal action against piracy". $\quad$ http://web.lexis-nexis.com/universe/document?_m= 54beca9d9ebe7d7b6787a5f6fd2b6eac...(Accessed 4/15/2004).

3. Associated Press Online (2004, March 25). "British campaign to target music piracy", http://web.lexisnexis.com/universe/document?_m=54beca9d9ebe7d7b6787a5f6fd2b6eac... (Accessed 4/15/2004).

4. Avalon, M. (2002), Confessions of a Record Producer. San Francisco, CA: Backbeat Books.

5. Avalon, M. (2004, May 5) "Neilsen rating system at odds with RIAA's claim of lost sales". Music Dish. http://www.kensei-news.com/bizdev/publish/factoids_us_article_23374.shtml (accessed 5/14/2004).

6. Bernstein, D. (2004, January 5) "Songwriters say piracy eats into their pay", New York Times, C6.

7. Buck v. Jewell-LaSalle Realty Co., 283 U.S. 191 (1931).

8. Ceola, N. (2003, November 24). "ARIA launches world first action against ISP". http://web.lexisnexis.com/universe/document? m=54 beca9d9ebe7d7b6787a5f6fd2b6eac... (Accessed 4/15/2004).

9. Department of Justice Press Release (2004, April 22). "Justice department announces international Internet piracy sweep 'Operation Fastlink' is the largest global enforcement action ever undertaken against online piracy”. http://www.usdoj.gov/criminal/cybercrime/fastlink.htm. (Accessed 5/7/2004)

10. $\quad$ Digital Theft Deterrence And Copyright Damages Improvement Act of 1999, 17 U.S.C. §504.

11. Evangelista, B. (2003, October 31) "RIAA pursues 80 more; suits filed against file sharers include 2 in Bay Area", San Francisco Chronicle, B1.

12. Hui, K. and Png, I. (2003). "Piracy and the legitimate demand for music". Contributions to Economic Analysis and Policy. 4(1).

13. McCullagh, D. (2004, March 31). "Ashcroft creates task force for copyright violations". CNET News.com, http://www.news.com/2102-1023_3-5182781.html (accessed 5/7/2004)

14. McGuire, D. (2004, March 29) study: "File-sharing no threat to music sales", Washington Post, http://www.washington post.com/wp-dyn/articles/A34300-2004Mar29.html (accessed 5/19/2004)

15. McGuire, D. (2004, March 31) "Lawmakers push prison for online pirates", Washington Post, http://www.washingtonpost.com/wp-dyn/articles/A40145-2004Mar31.html (Accessed 5/7/2004)

16. Moyers, B. (2002, April 26) Transcript: Virtual Radio PBS

17. Needham, K. and Jinman, R. (2003 November 22) "Can't stop the music". Sydney Morning Herald, p. 29

18. Nielsen SoundScan, http://www.soundscan.com/about.html

19. No Electronic Theft (NET) Act. (2004) 17 U.S.C. and 18 U.S.C as amended, www.usdoj.gov/criminal/cybercrime/17-18red.htm (accessed 4/22/04).

20. Oberholtzer, F. and Strumpf, K., (2004) "The effect of file sharing on record sales an empirical analysis".

21. Patry, W. (1994), Copyright Law and Practice Vol. I, Washington, D.C.: Bureau of National Affairs.

22. Piracy Deterrence and Education (PDEA) Act (2004) [HR 4077], http://www.public knowledge.org/content/legislation/hr4077 (accessed 5/7/2004) 
23. Raba, J., (2004) "Lawsuits, price-fixing, and the $\$ 5$ solution", U. California-Davis School of Law, http://web.lexis-nexis.com/universe/document?_m=54beca9d9ebe7d7b6787a5f6fd2b6eac...(accessed 4/15/ 2004)

24. Rainie, L. and Madden, M., Pew Internet Project data memo, Pew Internet \& American Life Project, Www.pewinternet.org (accessed 5/7/2004)

25. RIAA, http://www.riaa.com

26. RIAA v. Verizon, 351 F.3d 1229 (D.C. Cir. 2003).

27. Viega, A. (2004, March 24). "Recording industry sues alleged swappers". Associated Press. http://news.findlaw.com/ap_stories/high_tech/1700/3-24-2004/200403240830005_15.html (Accessed 3/30/ 2004)

28. $\quad$ White-Smith Music Publishing Company v. Apollo Company, 209 U.S. 1 (1909)

29. Zeidler, S. (2004, March 23). "Record industry sues 532 more U.S. file-sharers". Reuters. http://news.findlaw.com/entertainment/s/20040323/medialawsuitsdc.html

30. Zetner, A. (2004) "Measuring the effect of online piracy on music sales". Working paper. University of Chicago

Notes 
Notes 